\title{
História pública e literatura: reflexões sobre o discurso
}

\section{Public history and literature: reflections about the discourse}

\author{
Alexandre Santos de Moraes \\ asmoraes@gmail.com
}

Resumo

$\mathrm{O}$ artigo reflete sobre o tema do discurso no âmbito dos debates sobre História Pública. A partir da análise dos desenvolvimentos de um campo específico da Literatura Grega Arcaica, suscitamos alguns debates que permitem refletir sobre a posição dos historiadores e da audiência no movimento de produção e acesso ao discurso historiográfico.

Palavras-chave: História Pública; Poesia Oral; Literatura Grega Antiga.

\begin{abstract}
:
This paper offers a reflection on the theme of the discourse as part of the debates of Public History. From the analysis of the developments in a specific field of Archaic Greek Literature, we will promote a debate that allows reflection on the position of historians and their audience in the movement related to the production of and access to the historiographical discourse.
\end{abstract}

Keywords: Public History; Oral Poetry; Ancient Greek Literature.

* Professor Adjunto do Departamento de História e do Programa de Pós-graduação em História da Universidade Federal Fluminense. Membro do Núcleo de Estudos de Representações e de Imagens da Antiguidade (NEREIDA/UFF) e colaborador do Laboratório de História Antiga (LHIA/UFRJ). 
Artigos

É bem conhecido um passo da Poética em que Aristóteles afirma ser a Poesia mais elevada que a História porque "aquela enuncia verdades gerais; esta relata fatos particulares" (ARISTÓTELES, Poética, IX, 1451b). Essa afirmação seria incompreensível caso a deslocássemos do núcleo de preocupações estéticas do filósofo estagirita. Ainda que se ocupe das qualidades intrínsecas às narrativas - com ênfase, sem dúvida, nos aspectos da tragédia - a noção de kátharsis é decisiva para compreender os efeitos que caracterizam os discursos.

Admite-se com facilidade que a comunicação envolva, pelo menos, cinco níveis: emissor, receptor, mensagem, contexto, canal e código. ${ }^{1} \mathrm{O}$ esteticismo que perdurou da consolidação do campo literário (tradicionalmente situada no século XVIII) até, pelo menos, a década de 1960, tendia a insistir na primazia do autor sobre todos os elementos do discurso. Ainda que se postule, a partir da influência de Kant, "uma forte propensão a achar que o juízo estético pertence à categoria dos juízos que não tem a ver com a natureza do objeto, mas sim com o modo de sua recepção" (CARDOSO, 1999, p. 101), decerto que o estandarte era empunhado pelo gênio criativo que compunha as obras, e não pela segunda subjetividade envolvida no processo, a audiência: em geral, ela era entendida como a parte que dava a chancela para um discurso previamente estabelecido, sem dele participar como parte integrante.

Essa perspectiva também irradiou na direção dos estudos sobre a Poesia Grega Arcaica, em particular nas análises sobre a Ilíada e a Odisseia, notadamente quando do lançamento do livro Prolegomena ad Homerum, em 1795, escrito por Friedrich August Wolff, que, de modo seminal, questionava o suposto aedo cego de Quios como sendo o autor, fez vir à luz as epopeias mais celebradas da História do Ocidente. Desta forma, do final do século XVIII e ao longo de todo o século XIX, a assunção dos poemas como objeto de preocupação filológica gravitou em torno da noção de sua autoria e da longa tradição de oralidade a ela associada. Os debates foram - e continuam a ser - tão longos e exaustivos que as pesquisas chegaram a se aglutinar em torno da alcunha Questão Homérica, e não raro deparamos com o termo Homerologia, síntese da constatação de um campo de estudos que nasceu e prosperou em torno desta busca inquietante pelo autor e seu tempo histórico.

O cenário da Questão Homérica só mudou radicalmente quando os estudiosos tomaram consciência de que a literatura não se resume a um movimento unilateral da ação imaginativa de um sujeito que irradia seu brilhantismo para uma audiência que passivamente goza do deleite de sua máxima inspiração. A partir da década de 1930, os estudos de Milman Parry e Albert Lord articularam as características das narrativas a uma comparação com a execução de poemas orais tradicionais de bardos iugoslavos, de modo que duas outras variáveis da comunicação, antes escassamente refletidas pelos homeristas, foram adicionadas definitivamente ao rol de preocupações. Percebeu-se que "o público e o contexto da apresentação afetavam o poeta nitidamente" (THOMAS, 2005, p. 45). A ideia de autoria continuou a ser explorada, especialmente pela historicidade do nome de Homero, já que poucas décadas após a provável data de composição dos poemas nenhum grego da Antiguidade parecia duvidar de sua existência ${ }^{2}$. Além disso, há pesquisadores que analisam a possível interferência de um poeta individual, o chamado "Poeta Monumental", no conjunto da obra e que teria sido o responsável por assegurar a coerência dos milhares de versos (HEUBECK, 1978, p. 1-17; LOHMANN, 1970; WADE-GERY, 1952). No entanto, uma tendência de estudos fortemente radicada nos Estados Unidos, adepta à “Teoria Oral de Composição", tende a euforizar o valor da audiência e da correspondente afetação que provocava no desempenho dos poetas.

Como sublinha Gregory Nagy (2003, p. 9), um dos maiores entusiastas da tendência oralista, não se trata apenas de pensar a performance na poesia, mas igualmente a poesia como performance. Para não me alongar numa síntese que seria inexequível no espaço deste artigo, chamo a atenção para o aspecto que jul-

$1 \mathrm{Ou}$, numa perspectiva sensivelmente diferente, "esse esquema elementar se constitui de: emissor, receptor, código, referente e mensagem. Temos então que: o emissor transmite uma mensagem (informação) ao receptor, mensagem essa formulada em um código referido a algum elemento da realidade - o referente" (ORLANDI, 2010, p. 21).

2 Sobre este assunto, é impossível evitar a remissão ao artigo impecável de Martin West (1999, p. 364-382) sobre a consolidação da fama de Homero ao longo dos períodos Arcaico e Clássico. 
go mais apropriado na abordagem do autor: em suas análises, Nagy enfatiza a necessidade de abordar um "sistema poético" (poetic system), assumindo, desta forma, que o discurso é resultado de múltiplas tensões que concorrem de modo interdependente para a criação da narrativa (NAGY, 2003, p. 9). Questiona-se assim a posição hierárquica do autor como o único ponto de observação da experiência literária. Parece adequado, diante do exposto, resgatar um dos aspectos basilares da Análise de Discurso francesa e considerar que, em linhas gerais, "o discurso é efeito de sentidos entre locutores” (ORLANDI, 2010, p. 21).

Essas questões podem ser extremamente instigantes para refletirmos sobre a História Pública. Os estudos sobre a Poesia Grega Arcaica podem estimular a reflexão a respeito das posições que nós, historiadores, ocupamos diante do discurso histórico quando ele extrapola as muralhas das universidades. Mais que isso, considero apropriado problematizar essa experiência como um sistema discursivo, tal como sugere Gregory Nagy, no qual concorrem inúmeros fatores que precisam ser seriamente problematizados na realização e como realização de um discurso histórico.

Penso que todos nós estamos razoavelmente de acordo que a grande maioria dos saberes produzidos no ambiente universitário é absolutamente hostil aos "não iniciados". Historiadores escrevem para historiadores. Essa hostilidade não se radica apenas na necessidade de prévia compreensão do aparato teórico-metodológico ou da linguagem característica que ao longo do tempo foi se conformando como aquela que seria adequada para a escrita de nossas monografias, dissertações, teses e demais resultados de pesquisas. A questão está alhures, ab ovo, quiçá na escolha dos temas que aprendemos como sendo aqueles que estão disponíveis pelo cânone universitário e que podem se tornar, em detrimento de uma miríade de outros tantos, como legítimos espaços de atuação profissional. Neste sentido, é certo que a noção de uma História Pública já evoca um novo horizonte de possibilidades de produção do discurso: ainda que passando pela universidade, é provável resultado da constatação primeira de que, como autores (ou emissores), não possuímos (ou deveríamos possuir) o monopólio do saber histórico.

Dos muitos resultados possíveis que decorrem do incremento das preocupações em torno da História Pública, consta a possibilidade de repensar a produção do discurso, a abertura para a reflexão e uso de novos canais e, até mesmo, a emergência de críticas a algumas posturas epistemológicas tradicionais. ${ }^{3}$ No entanto, um dos traços mais explorados no âmbito da História Pública, desde a emergência dos debates na década de 1970, tem a ver exatamente com os sentidos de e do Público que qualificam esta vereda do saber de Heródoto. É por aí que os estudos oralistas a respeito da Poesia Grega Arcaica podem sugerir caminhos bastante proveitosos: que outros elementos concorrem para a produção de um discurso histórico mais abrangente? Qual a posição e a participação do público? Que influência os canais de comunicação exercem? Sobretudo, como o historiador se posiciona diante desta série de novas variáveis?

Por princípio, nenhuma dessas perguntas pode ser respondida com seriedade sem considerar estudos de caso particulares. Pela mesma razão, não parece prudente estabelecer modelos ou regras gerais. Assim como não há uma definição geral de Literatura, "que só pode ser uma noção historicamente definida” (CARDOSO, 1999, p. 103), também não há uma medida para analisar esta série de questões em um campo tão diversificado. O que podemos fazer é indicar algumas posturas que parecem mais produtivas que outras.

No caso da chamada História Digital, por exemplo, a tendência, como o nome sugere, é de reconhecer o canal da comunicação como o núcleo das preocupações teóricas e, sobretudo, metodológicas. No artigo Interchange: The Promise of Digital History, resultado de uma entrevista feita pelo The Journal of

3 Jacques Le Goff (2003, p. 29), no célebre História e Memória, chegou a defender a existência de pelo menos duas histórias: a da memória coletiva, em geral deformada e falseada, e a dos historiadores, cuja tarefa por ele atribuída era quase messiânica: "Em primeiro lugar, porque há pelo menos duas histórias, e voltarei a este ponto: a da memória coletiva e a dos historiadores. A primeira é essencialmente mítica, deformada, anacrônica, mas constitui o vivido desta relação nunca acabada entre o presente e o passado. É desejável que a informação histórica, fornecida pelos historiadores de ofício, vulgarizada pela escola (ou pelo menos deveria sê-lo) e pela mass media, corrija esta história tradicional falseada. A história deve esclarecer a memória e ajudá-la a retificar os seus erros. Mas estará o historiador imunizado contra uma doença, se não do passado, pelo menos do presente e, talvez, uma imagem inconsciente do futuro sonhado?”. 
Artigos

American History junto a uma série de historiadores envolvidos com a questão ${ }^{4}$, os olhares da audiência e da autoria são subordinados às potencialidades que os computadores oferecem para a representação do passado. William G. Thomas, que arroga pra si a autoria do termo História Digital quando, ao lado de Ed Ayers, fundou o Virginia Center for Digital History em 1997, assim define esse campo de atuação:

História Digital é uma abordagem para analisar e representar o passado que trabalha com novas tecnologias do computador, da Internet e dos sistemas de softwares. Por um lado, história digital é uma arena aberta de produção e comunicaşão científicas, abrangendo o desenvolvimento de novos materiais e coleções de arquivos acadêmicos. Por outro lado, é uma abordagem metodológica moldada pelo poder do hipertexto de tais tecnologias para faz̨er, definir, consultar e anotar associações nos registros humanos do passado. Faz̨er história digital, portanto, é preciso criar um quadro, uma ontologia, através da tecnologia, para que as pessoas leiam, experimentem e sigam uma discussão acerca dos problemas históricos (COHEN, 2008, p. 254).

Uma definição como esta, que subordina a produção do discurso às potencialidades do suporte de informação, tende a oferecer um espaço pouco proveitoso para pensar a respeito da posição que as subjetividades ocupam na definição dos conteúdos que serão lembrados e esquecidos. Tem-se uma aparente democratização dos processos de escolha, onde emissor e receptor parecem ocupar uma posição simétrica dentro desta "arena aberta de produção", desconsiderando assim que a maioria (ou, talvez, todos) dos sistemas discursivos, justamente por serem produtos de múltiplas tensões e influências, envolvem relações de poder entre as partes envolvidas.

À época, o entusiasmo com a possibilidade de difusão do conteúdo que a internet oferecia não parecia abalado pelo ceticismo que gradualmente foi tomando espaço. Na mesma entrevista, Amy Murrell Taylor ressaltou que 1,3 bilhão de pessoas no mundo dispõem de acesso à Internet, ampliando o público potencial de uma forma impossível de imaginar (COHEN, 2008, p. 464). Ainda que se advogue que afirmações deste tipo representam estratagemas retóricos para valorizar o campo, não parece prudente considerar que a mera disposição das informações seja um fator decisivo para a atração de novas audiências, em especial no ambiente virtual, onde a profusão de dados e a possibilidade de acessá-los estão envolvidas tanto pelas motivações do usuário quanto pelos limites de publicidade que tais informações dispõem. Em outras palavras, o acesso a determinado conteúdo depende não apenas do interesse da audiência, mas da capacidade que determinado site tem para se tornar, em primeiro lugar, visível e, em segundo lugar, atrativo. É possível que uma parte significativa dos conteúdos de nossa área só tenha acesso garantido a partir de uma divulgação fora do ambiente virtual.

Decorre daí um segundo problema, qual seja, o de considerar que no momento atual, em que a História se torna disponível por meio de uma quantidade extremamente ampla de suportes (televisão, rádio, revistas, jornais, internet e "lugares de memória", como museus, bibliotecas e arquivos, por exemplo), a atração de novas audiências se resuma a estratégias de marketing, muitas vezes tratando a História como mais um produto da chamada "Indústria Cultural". Decerto, e ainda que não esteja entre minhas preocupações particulares, é fácil perceber que há um mercado consumidor para além do público especializado que compra revistas de divulgação científica, que assiste ao The History Channel e que compra livros que muitas vezes vendem a promessa de oferecer uma alternativa à História aprendida na Educação Básica, sem contar os que exploram biografias de personagens polêmicas. Hitler é aposta certa. Sucesso garantido.

Para além do fator comercial, a análise das audiências é decisiva para refletir sobre a necessidade que o mundo moderno cria em torno da História. Talvez seja esse ponto que direciona os historiadores a expandir e democratizar debates em torno da ideia de justiça social ou, com base na inter-relação entre história e memória, da valorização da construção das identidades coletivas (ALMEIDA \& ROVAI, 2013, p. 1). Esses esforços, contudo, seriam incipientes caso considerássemos a História Pública como sendo, por excelência, "a forma e natureza da transmissão da História para uma audiência mais vasta" ou, conforme John Tosh, como “o livre acesso do público que busca por pesquisas históricas” (TOSH, 2008, p.

4 Especificamente, os historiadores Daniel J. Cohen, Michael Frisch, Patrick Gallagher, Steven Mintz, Kirsten Sword, Amy Murrell Taylor, William G. Thomas e William J. Turkel. 
119). Como ocorreu com os estudos sobre a Poesia Grega Arcaica, estaríamos diante de um movimento em que o historiador representa a única parte ativa do processo.

Alguns autores já tomaram consciência de que a unilateralidade do discurso não é apenas uma utopia, mas a receita de um projeto fracassado. O esforço para atingir audiências mais amplas não se resume a uma simples mudança da linguagem ou, quem sabe, a um esforço para atenuar, ainda que criteriosamente, as exaustivas discussões teóricas e metodológicas. Como bem salientou Jo Blatti, essa questão é particularmente significativa quando associada aos domínios da História Oral, cujas técnicas de pesquisa exigem uma negociação entre o narrador, o entrevistador e, finalmente, o receptor. Deste modo, "a troca e a negociação, que estão no centro da História Oral, prefiguram a relação entre audiência e historiadores no âmbito da História Pública" (BLATTTI, 1990, p 616).

Ora, se o discurso é efeito de sentido entre locutores, é indispensável que tais sentidos estejam submetidos à negociação: emissor e receptor devem negociar as possibilidades de construção do discurso histórico falando uma mesma língua, ou seja, partilhando o mesmo código, de acordo com as possibilidades dadas pelos canais de comunicação. É por esse caminho que Hilda Kean e David Thelen (2010, p. 27) assumiram que "o passado deve ser tratado como uma experiência humana compartilhada e oportunidade para compreensão, ao invés de um terreno para a divisão e desconfiança". Daí a defesa da autora em torno da construção de um movimento participativo, que vincule os historiadores às demandas que o público tem em relação ao passado e que o faça considerar, ainda, como parte integrante deste grupo (KEAN \& THELEN, 2010, p. 28).

A constatação, ainda que pareça óbvia, exige a mais profunda consideração: é improvável que a História ultrapasse as muralhas das universidades, se os historiadores permanecem reféns da clausura. Como defendi no início, não há regras ou modelos gerais capazes de orientar o movimento de publicidade da historiografia. No entanto, a negociação pode ser duplamente proveitosa: além de ampliar exponencialmente os ouvidos sensíveis aos discursos do historiador, pode aumentar a sensibilidade do historiador aos muitos discursos possíveis.

\section{Bibliografia}

ALMEIDA, Juniele Rabêlo de; ROVAI, Marta Gouveia de Oliveira. História Pública: entre "políticas públicas” e os "públicos da história”. In: Anais do XXVII Simpósio Nacional de História. Natal: ANPUH, 2013.

BLATTI, Jo. Public History and Oral History. In: The Journal of American History, v. 77, n. 2, 1990, p. 615625.

CARDOSO, C. F. Tinham os antigos uma Literatura? In: Phoînix, n. 5, v. 1, 1999, p. 101.

COHEN, D. J.; FRISCH, M.; GALLAGHER, P.; MINTZ, S. SWORD, A. M. T.; THOMAS, W. G.; TURKEL, W. J. Interchange: The Promise of Digital History. In: The Journal of American History, v. 95 , n. 2, 2008,

HEUBECK, M. Homeric studies today: results and prospects. In: FENIK, B. (ed.). Homer, Tradition and Invention. Leiden: E. J. Brill, 1978, p. 1-17

LE GOFF, Jacques. História e Memória. Campinas, SP: Editora da Unicamp, 2003.

LOHMANN, D. Die Kompositionen der Reden in der Ilias. Berlin: Gruyter, 1970

NAGY, G. Homeric Responses. Texas: The University of Texas Press, 2003,

ORLANDI, E. P. Análise de Discurso: Princípios \& Procedimentos. São Paulo: Pontes, 2010. 
Artigos

TOSH, John. Why History Matters. Basingstoke: Palgrave Macmillan, 2008.

THOMAS, R. Letramento e oralidade na Grécia Antiga. São Paulo: Odysseus, 2005.

WADE-GERY, H. T. The Poet of the Iliad. Cambridge: The Cambridge University Press, 1952.

WEST, M. The Invention of Homer. In: The Classical Quarterly, v. 49, n. 2, 1999, p. 364-382. 